\title{
Interactive comment on "Sensitivity of formaldehyde (HCHO) column measurements from a geostationary satellite to aerosol temporal variation in East Asia" by Hyeong-Ahn Kwon et al.
}

Anonymous Referee \#2

Received and published: 2 November 2016

The comment was uploaded in the form of a supplement:

http://www.atmos-chem-phys-discuss.net/acp-2016-712/acp-2016-712-RC1-

supplement.pdf

Interactive comment on Atmos. Chem. Phys. Discuss., doi:10.5194/acp-2016-712, 2016. 